\title{
Immunolocalization of Lipoxygenase in the Anther Wall Cells of Lathyrus undulatus Boiss. during Programmed Cell Death
}

\author{
Filiz VARDAR', Meral ÜNAL \\ Marmara University, Science and Art Faculty, Department of Biology, Göztepe, 34722, İstanbul, \\ Turkey; filiz.vardar@gmail.com ('correspondingauthor),meralunal@marmara.edu.tr
}

\begin{abstract}
Lipoxygenase catalyzes oxygenation of long chain fatty acids to hydroperoxides and is involved in the degradation of membranes occuring in some types of programmed cell death (PCD). The localization of lipoxygenase in the anther wall layers of $L$. undulatus during cellular degradation was analyzed by immunogold labeling technique at young and vacuolated pollen stage, due to the close relation between lipoxygenase activity and membrane degradation in programmed cell death. Immunoreaction to lipoxygenase was monitored slightly at young pollen stage in the anther wall cells. As programmed cell death signals progress, lipoxygenase revealed in anther wall cells intensely. At vacuolated pollen stage tapetal cells came forward with ultrastructural changes such as cell, organelle and membrane disintegration. At the indicated stage immunogold particles indicating sites of LOX PAb-binding epitopes were located in the nucleus (chromatin was condensed and lined at the periphery), cytoplasm and close to long dilated rough endoplasmic reticulum (RER) cisterna. In conclusion lipoxygenase increase which has a role in the membrane degeneration, possibly induced the collapse of tonoplast, nuclear and plasma membrane and triggered programmed cell death in the tapetal cells of $L$. undulatus as well as the other wall cells.
\end{abstract}

Keywords: anther, Lathyrus undulatus, lipoxygenase, Programmed Cell Death, tapetum

\section{Introduction}

Programmed cell death (PCD) is a ubiquitous active process that occurs in the course of development and in response to biotic and abiotic stresses. PCD has been represented in animal cells in great detail at the morphological, biochemical and molecular levels (Hale et al., 1996; Fadok et al., 1998). It has been reported that reactive oxygene species, $\mathrm{H}_{2} \mathrm{O}_{2}$ and lipid peroxides have been long considered crucial elements of apoptosis in animals (Hockenbery et al., 1993; Torres-Roca et al., 1995). More recently the peroxides produced by lipoxygenase (LOX) activity have received attention as mediators of apoptosis (Wagenknecht et al., 1997; Maccarrone et al., 1999). Remarkably, lipoxygenase-dependent pathways are implicated also in plant response to abiotic stress (Conconi et al., 1996) and development of hypersensitive response (Rusterucci et al., 1999). Moreover it has been reported that LOX is supposed to mediate the formation of superoxide anion in senescent plants (Lynch and Thompson, 1984).

LOXs (EC 1.13.11.12) are nonheme iron-containing dioxygenases widely distributed in plants and animals (Porta and Rocha-Sosa, 2002). LOX catalyzes oxygenation of long chain fatty acids to hydroperoxides and is involved in the degradation of membranes occuring in some types of PCD (Szczuka et al., 2006). It has been known that LOX which generates the peroxides are potentially toxic for cell membrane and therefore would not be expected to accumulate in plant tissues. These peroxides are quickly metabolized in chemical compounds involved in signaling, plant defense and PCD (Siedow, 1991; Gigot et al., 2010).

Although LOX is involved in a number of important processes in plant cells, its physiological function is still not fully understood. It has been reported that, high activity of LOX is also related to early development stages of plant growth (Schmitt and van Mechelen, 1997). Nowadays, LOX have been found in a lot of varieties of plants and organs, such as brassica flowers (Galliard and Chan, 1980), soybean seeds (Axerold et al., 1981), bean seedlings and cotyledons (Porta et al., 1999), olive fruit (Lorenzi et al., 2006), Gagea anthers (Szczuka et al., 2006) and dry fruits (walnuts, almonds, etc.) (Buranasompob et al., 2007). Kato et al. (1992) indicated that LOX is distributed in plant organs according to the type of environmental conditions, and the age of the plant.

In the previous studies, a detailed analysis of the development and PCD events in the anther wall cells of Lathyrus undulatus Boiss. was undertaken (Fabaceae) by light, fluorescence and electron microscopy (Vardar, 2008; Vardar and Ünal, 2011). The present paper provides to reveal the localization and possible role of LOX during PCD of Lathyrus undulatus Boiss. anther wall cells by immunogold labeling technique. 
72

\section{Material and methods}

Immunogold labelling was applied according to Szczuka et al. (2006). Flower buds were fixed in 2\% paraformaldehyde and 1\% glutaraldehyde dissolved in 0.05 $\mathrm{M}$ cacodylate buffer, $\mathrm{pH} 7.4$ for $24 \mathrm{~h}$ at $4^{\circ} \mathrm{C}$. The samples were rinsed several times in the buffer and embedded in Epoxy resin. Ultrathin sections $(\sim 70 \mathrm{~nm})$ were collected on nickel grids, and incubated first in $1 \%$ bovine serine albumin (BSA) in cacodylate buffer for $30 \mathrm{~min}$ at room temperature (RT), then with pre-immune rabbit serum (Agrisera, Sweden) diluted 1/1000 in buffer-BSA for $1 \mathrm{~h}$ at RT. After three times washing with buffer-BSA (10 min each wash) the sections were incubated with buffer-BSA containing rabbit anti-LOX antiserum (Agrisera, Sweden) diluted $1 / 1000$ for $1 \mathrm{~h}$ and repeatedly washed with bufferBSA. Goat antirabbit immunoglobulins conjugated to 10 nm gold particles (GAR-gold) (Sigma) were diluted 1/50 in buffer-BSA and then applied for $40 \mathrm{~min}$ at RT. The sections were washed several times with buffer and distilled water. For negative control, samples were incubated with pre-serum and GAR-gold or with GAR-gold only, omitting the primary antiserum. The sections were stained with $2 \%$ uranyl acetate for $5 \mathrm{~min}$ and lead citrate for $1 \mathrm{~min}$. All sections were examined with a JEOL JEM 1011 electron microscope.

\section{Results and discussion}

The localization of LOX in the anther wall layers of L. undulatus during cellular degradation was analyzed by immunogold labeling technique at young and vacuolated pollen stage, due to the close relation between LOX ac- tivity and membrane degradation in PCD. Immunogold labeling revealed the subcellular localization of epitopes binding lipoxygenase primary antibody (LOX PAb) in the anther wall cells.

As it was previously described, the anther wall is consisted of epidermis, endothecium, middle layer and tapetum in Latbyrus undutus (Vardar and Ünal, 2011). The single-layered epidermis remained intact up to anthesis. Endothecial cells acquired thickenings beginning from the vacuolated pollen stage. Middle layer was ephemeral and crushed at young pollen stage. The secretory tapetum underwent substantial changes in cell organization including nucleus morphology typical for PCD at the end of the young pollen stage. As PCD progresses along with the central vacuole collapse the tapetal cells reduced and underwent progressive disintegration and degeneration at vacuolated pollen stage. At bicellular stage tapetal cells degraded entirely, epidermis and single row U-shaped endothecium existed in mature anther wall (Vardar, 2008; Vardar and Ünal, 2011).

Immunoreaction to LOX was slightly monitored in the peripheral cytoplasm of flattened epidermal cells and endothecium at young pollen stage (Fig. 1). At this stage central vacuole was progressive and the cytoplasm locates at the cell periphery. In the course of vacuolated microspore stage, cells underwent structural disintegration and organelles showed conspicuous changes. Besides a positive immunoreaction to LOX was monitored in the central vacuole, cytoplasm (near the degenerated organelles) and near the cell wall in the epidermal cells (Fig. 2). At the indicated stage, immunolabelling to LOX in the endothecial cells was more intense than in the epidermal cells. Immunogold particles were observed intensively in

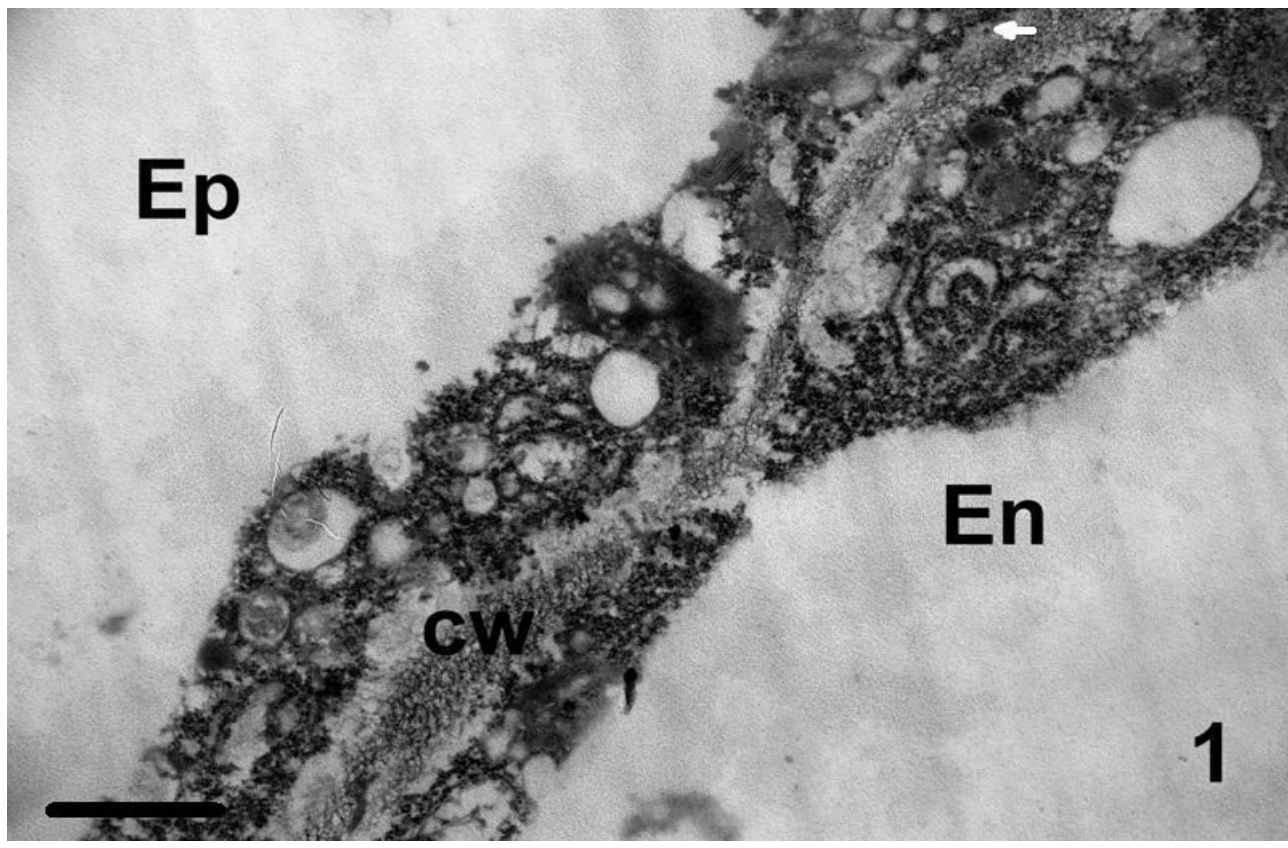

Fig. 1. Immunoreaction to LOX (white arrow) in the epidermis and endothecium at young pollen stage. cw: cell wall, En: endothecium, Ep: Epidermis. Bar: $0.5 \mu \mathrm{m}$ 


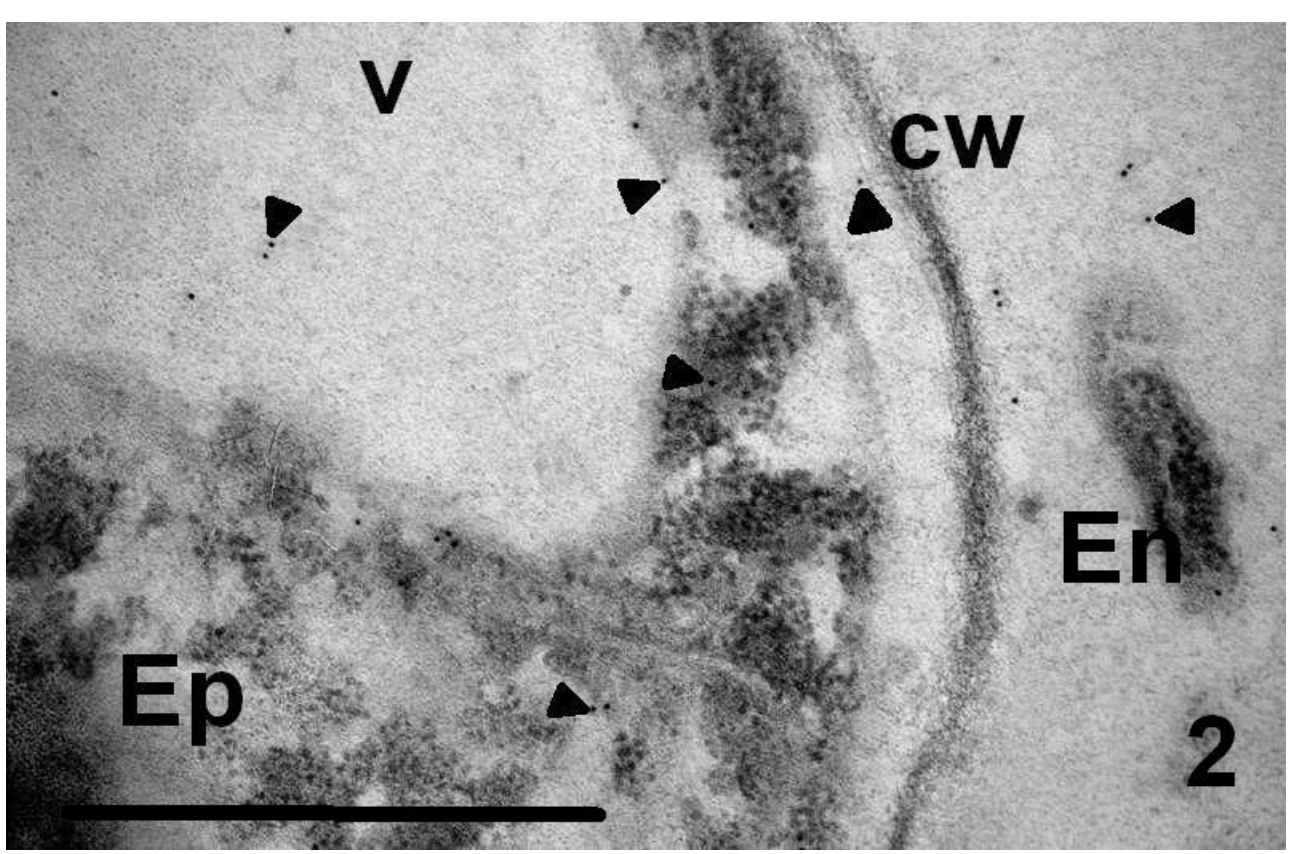

Fig. 2. Immunoreaction to LOX (black arrow heads) in the epidermis at vacuolated pollen stage. cw: cell wall, En: endothecium, Ep: Epidermis, v: vacuole. Bar: $0.5 \mu \mathrm{m}$

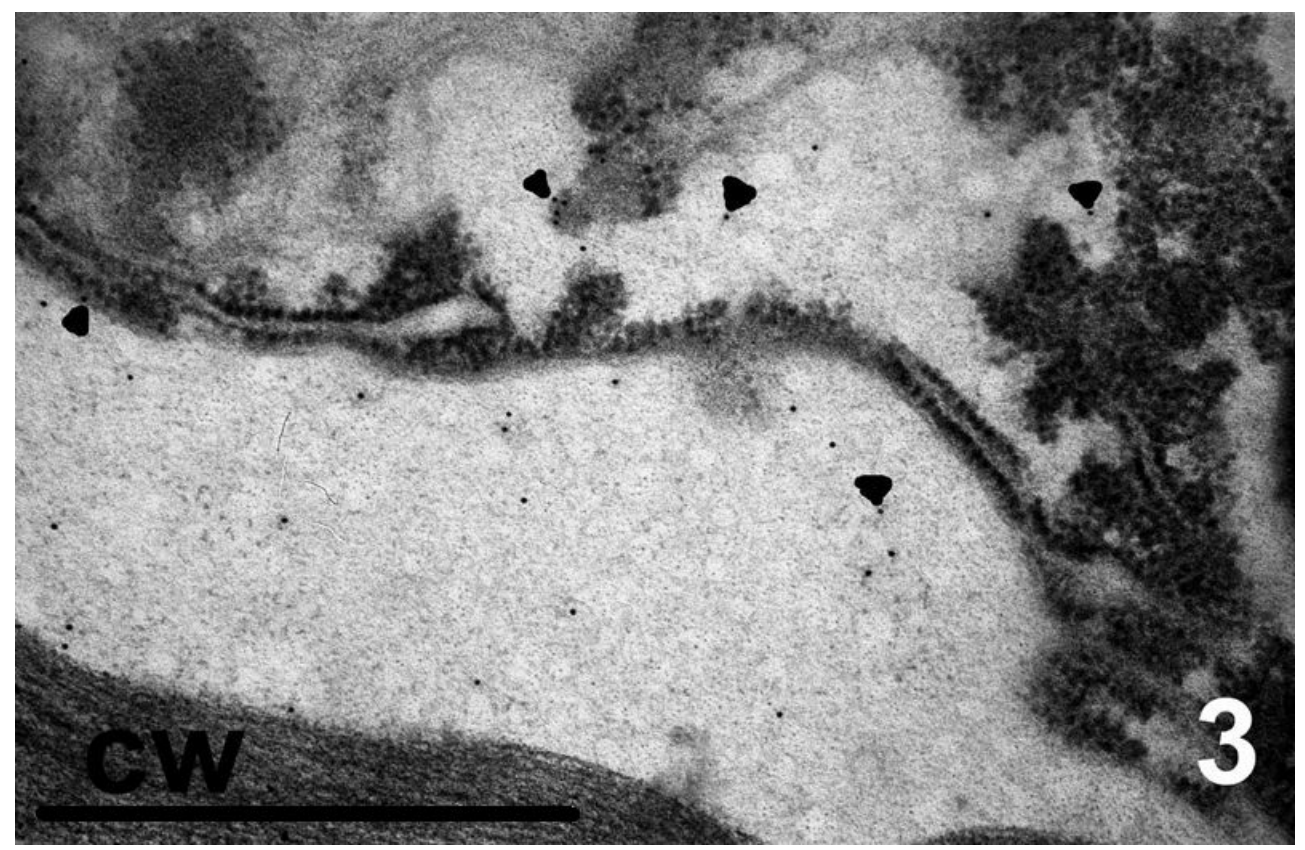

Fig. 3. Immunoreaction to LOX (arrow heads) in the endothecium at vacuolated pollen stage. cw: cell wall. Bar: $0.5 \mu \mathrm{m}$

the cytoplasm of cells of this subepidermal layer. Particles spread mainly in the peripheral cytoplasm, around dilated rough endoplasmic reticulum (RER) elements. Close to the thicker radial cell walls scattered particles were apparent (Fig. 2, 3).

Middle layer underwent disintegration and cell death at the beginning of young pollen stage (Vardar and Ünal, 2011). At vacuolated pollen stage the flattened and crushed cells of the middle layer contained remnants of disintegrated cytoplasm. The positive immunoreaction to
LOX was less intense than in the cells of both epidermis and endothecium. Immunogold particles were concentrated at the cytoplasm (Fig. 4, 5).

At the beginning of young pollen stage no degeneration signals and immunogold particles were observed at the tapetal cells (Fig. 6). The substantial changes in the cell and rare immunogold particles were first monitored at the end of young pollen stage.

At the stage of vacuolated pollen, tapetal cells showed definite signs of degeneration characterized of PCD 
74

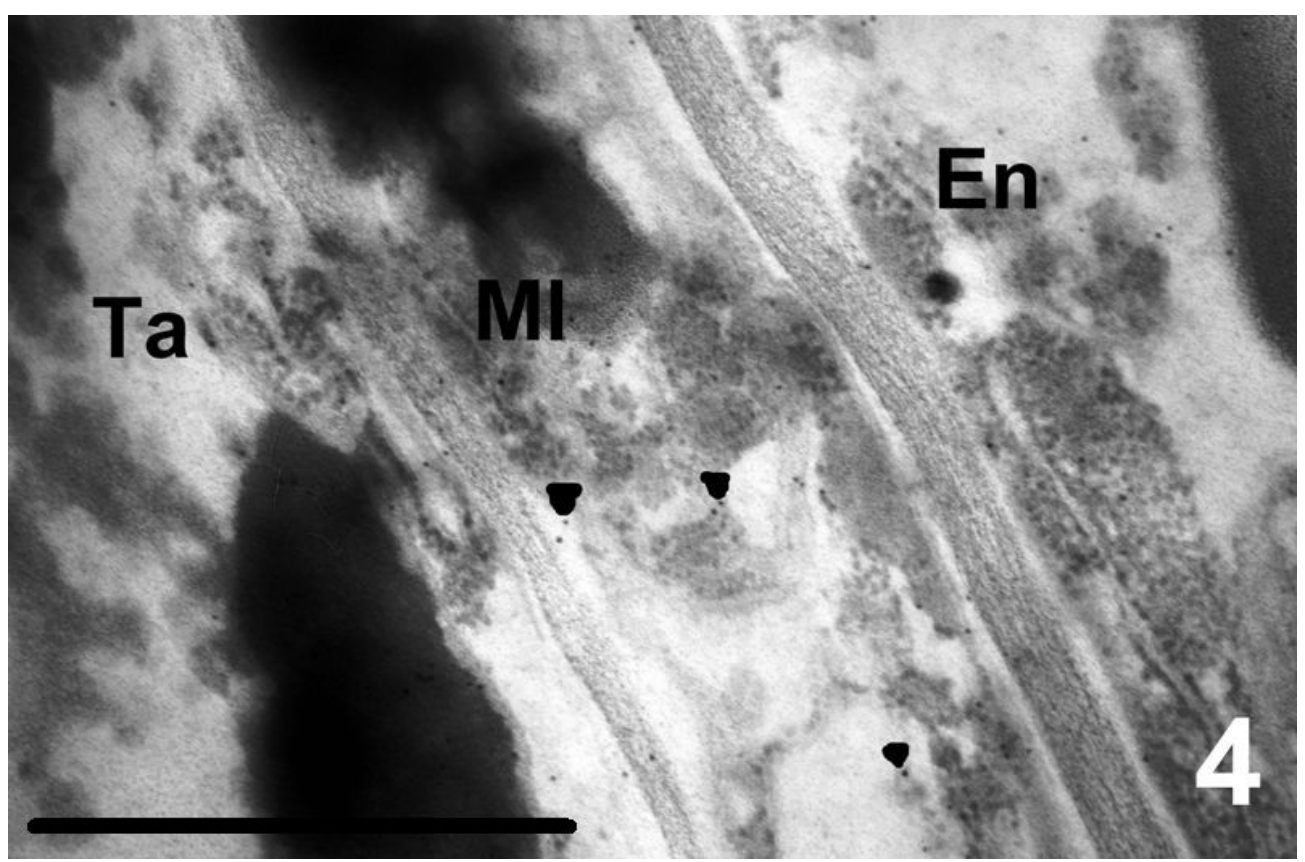

Fig. 4. Immunoreaction to LOX (arrow heads) in the middle layer at young pollen stage. En: endothecium, Ml: middle layer, Ta: tapetum. Bar: $0.5 \mu \mathrm{m}$

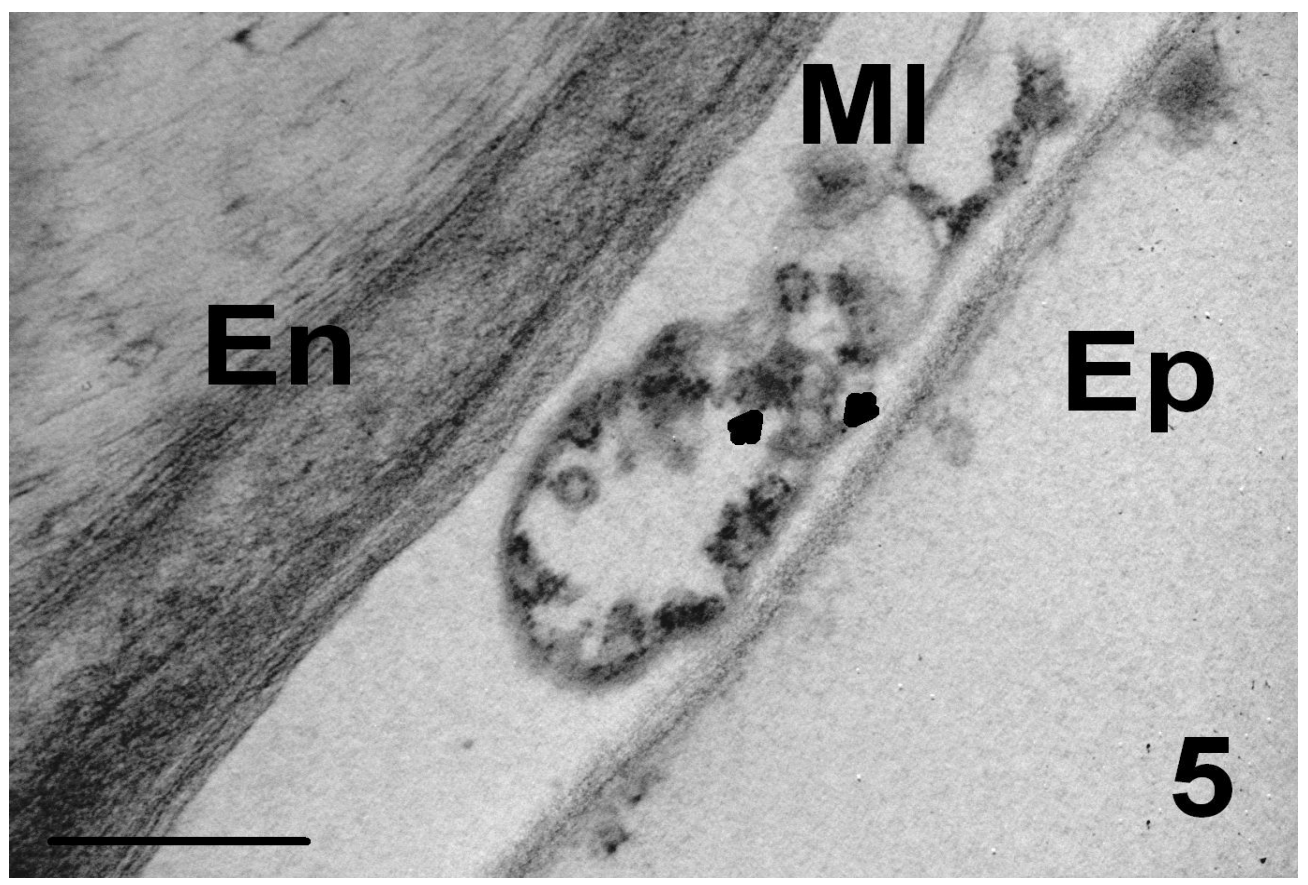

Fig. 5. Immunoreaction to LOX (arrow heads) in the remnants of middle layer at vacuolated pollen stage. En: Endothecium, Ep: Epidermis, Ml: middle layer. Bar: $0.5 \mu \mathrm{m}$

(Vardar and Ünal, 2011). All tapetal organelles showed conspicuous changes in the ultrastructure compared to the previous stages. Moreover plasma membrane was no longer recognizable, and central vacuole degenerated with the breakdown of the tonoplast (Vardar, 2008). At this stage immunogold particles indicating sites of LOX PAbbinding epitopes were located in the nucleus (chromatin was condensed and lined at the periphery), cytoplasm and close to long dilated RER cisterna (Fig. 7-9).

To determine the degree of specificity of the immunogold reaction, a control reaction for the whole procedure was run. The control reaction omitted incubation with the primary antibody but not incubation with or without preserum. The reactions showed no gold particles (Fig. 10). 


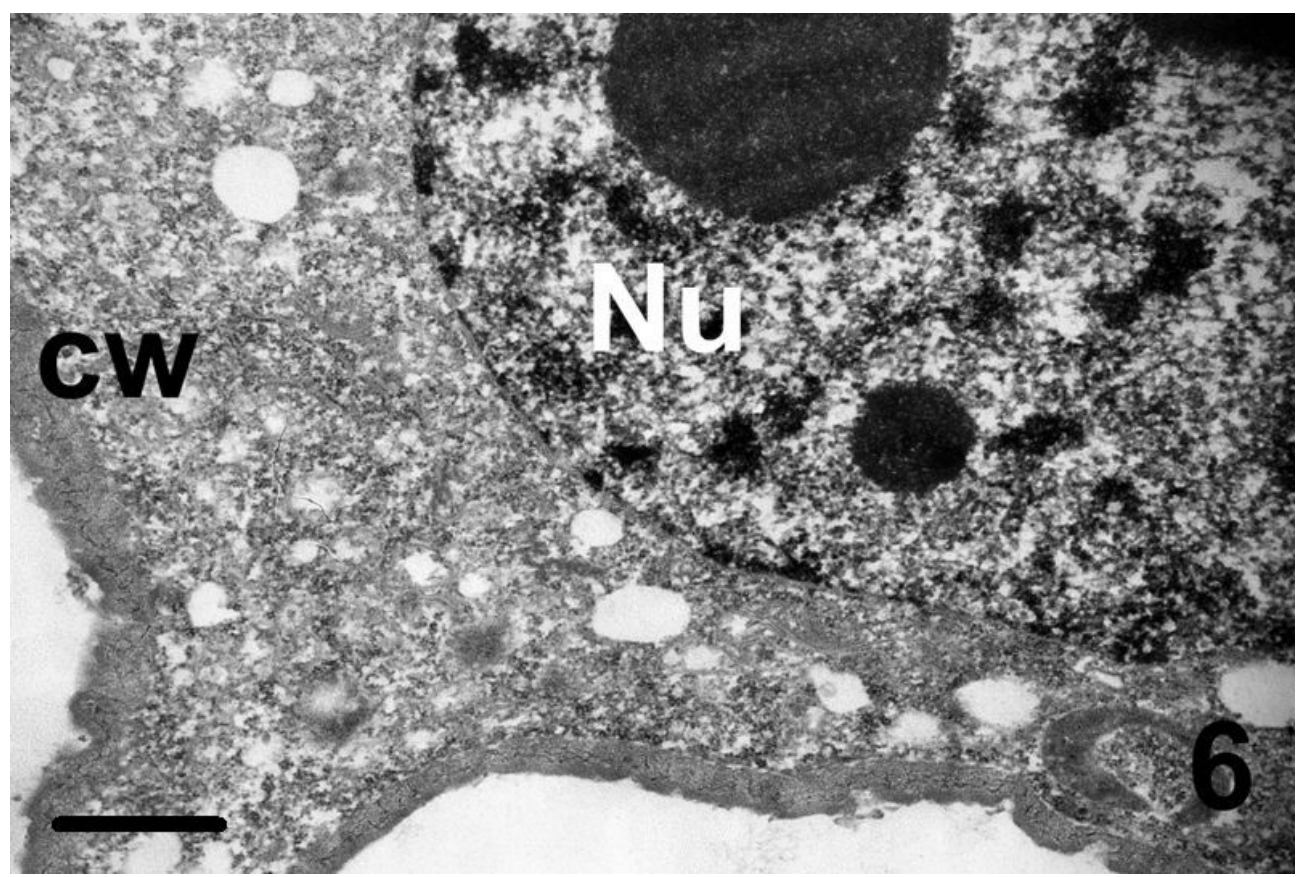

Fig. 6. No immunoreaction to LOX in the tapetum at young pollen stage. cw: cell wall, Nu: Nucleus. Bar: $0.5 \mu \mathrm{m}$

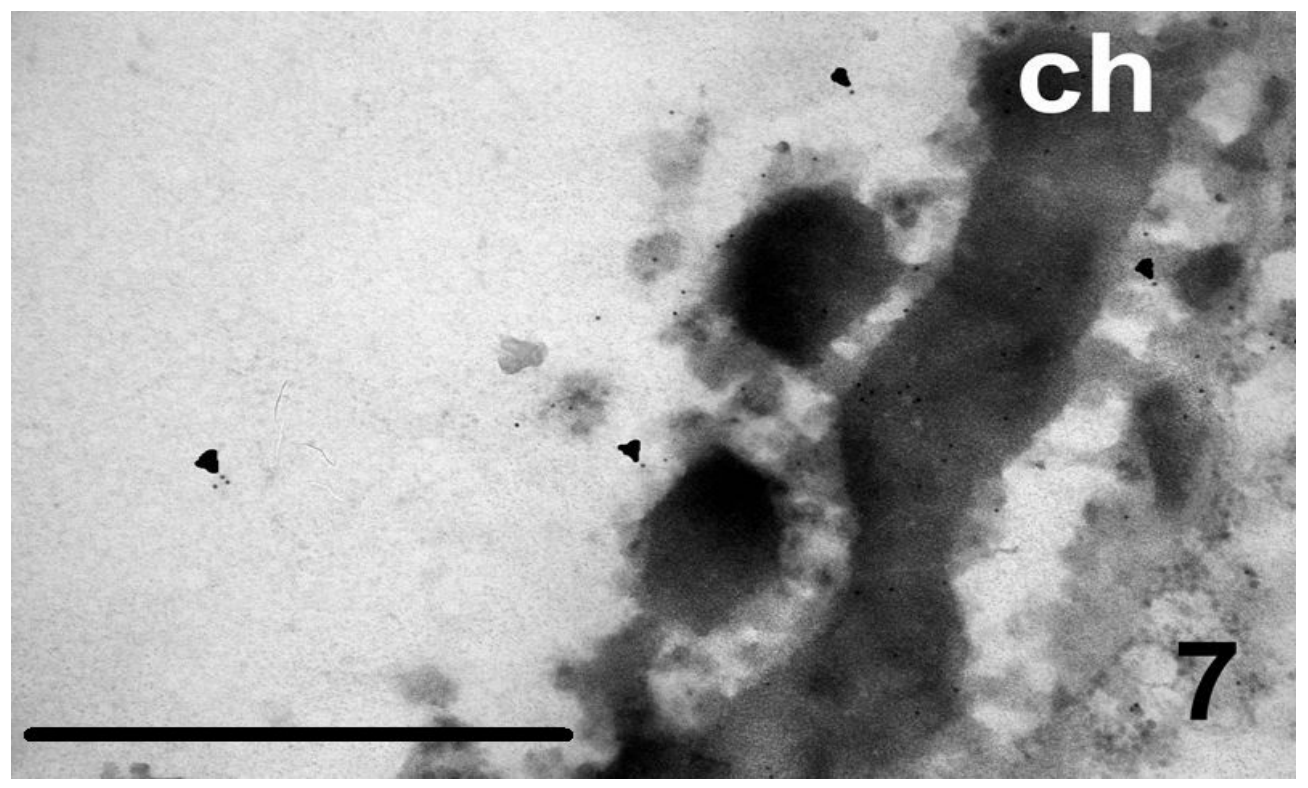

Fig. 7. Immunoreaction to LOX (arrow heads) in the nucleus (condensed chromatin lining at the periphery) of tapetum at vacuolated pollen stage. ch: chromosome. Bar: $0.5 \mu \mathrm{m}$

As it was previously described, the progressive diagnostic features were observed in the anther wall cells of $L$. undulatus at vacuolated pollen stage. It was well documented that tapetal cells of $L$. undulatus underwent substantial changes in cell organization including nuclear membrane degeneration, vacuole collapse according to tonoplast rupture, shrinkage of the cytoplasm, the increase and enlargement of the endoplasmic reticulum cisternae and disruption of the plasma membrane (Vardar, 2008; Vardar and Ünal, 2011). The presented study indicated that LOX
PAb-binding epitopes appeared intensely at vacuolated pollen stage in the anther wall cells.

Szczuka et al. (2006) confirmed the immunolocalization of LOX in the anther wall cells and pollen grains at the stage of pollen grain release to the anther loculus. However, the researchers focused on the localization of LOX and the relation between LOX and the lipidic structures such as sporopollenin and pollen coat. Likewise, several reserachers revealed the localization of individual isoforms of LOX in different cellular compartments, such as 
76

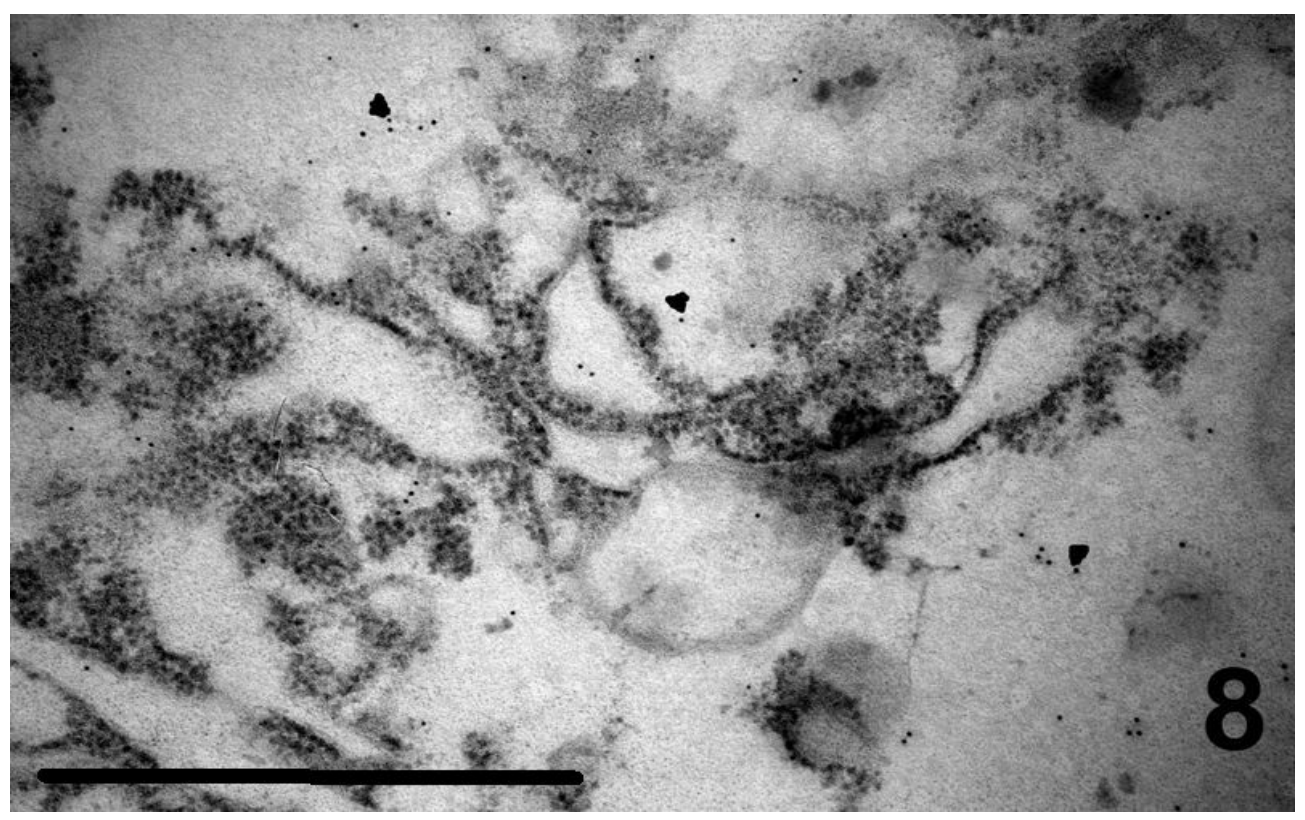

Fig. 8. Immunoreaction to LOX (arrow heads) in the cytoplasm of tapetum at vacuolated pollen stage. Bar: $0.5 \mu \mathrm{m}$

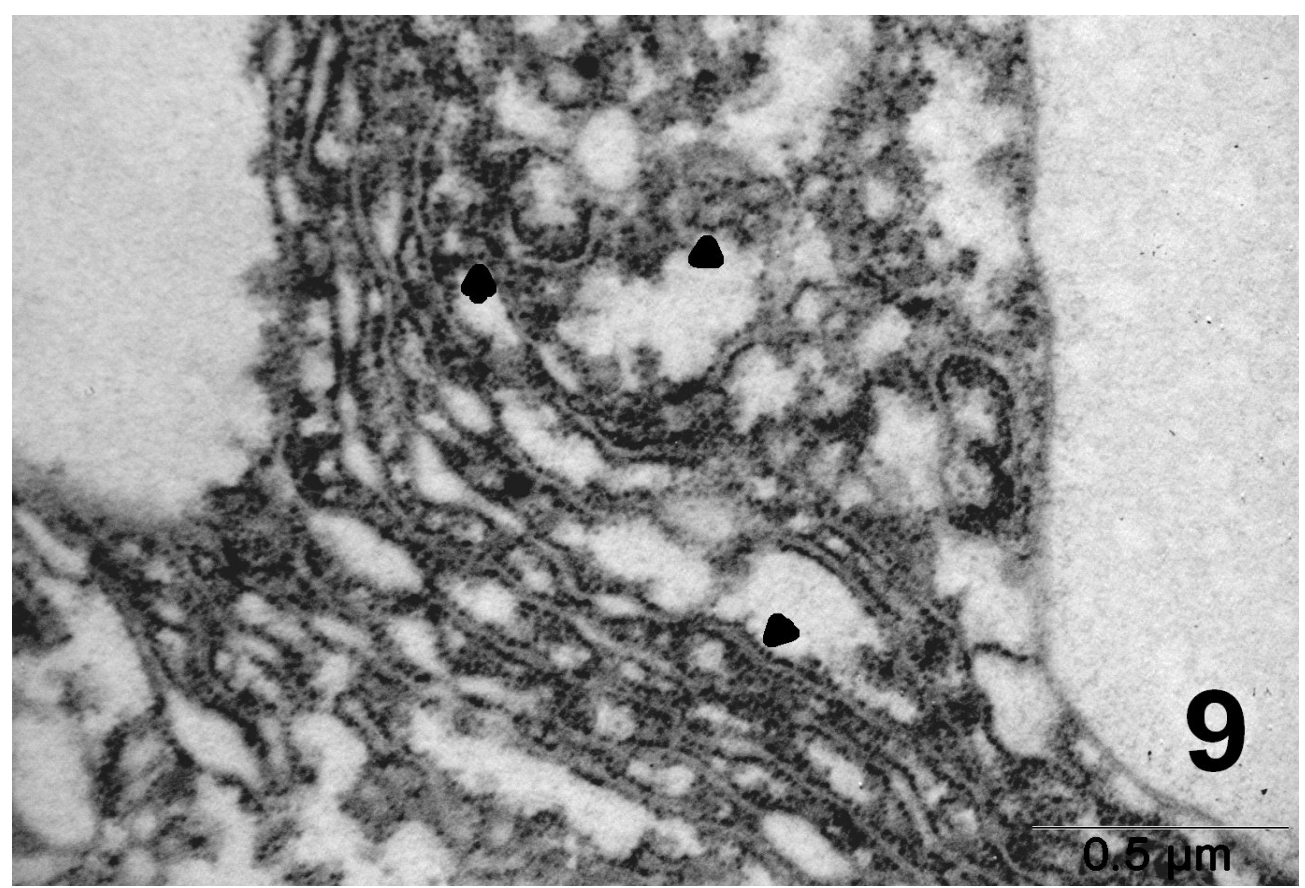

Fig. 9. Immunoreaction to LOX (arrow heads) in the dilated RER of tapetum at vacuolated pollen stage. Bar: $0.5 \mu \mathrm{m}$

cytosol (Siedow, 1991), chloroplast (Bowsher et al., 1992), microsomal membranes (Todd et al., 1990), plasmalemma (Vianello et al., 1995) and vacuoles (Wang et al., 1999).

Maccarrone et al. (2000) have paid attention to LOXmembrane lipid peroxidation-PCD relation in lentil root protoplasts induced by oxidative stress. LOX has been described to dioxygenate membrane lipid constituents and to generate conjugated hydroperoxides in the lipid bilayer
(Feussner et al., 1997). Alteration of membrane might be effective in the execution of the PCD, as described in animal apoptosis (Maccarrone et al., 1998). It seems noteworthy that the involvement of a LOX in membrane damage has been suggested during hypersensitive response of beans (Croft et al., 1990) and peppers (Bunaurio and Servili, 1999). 


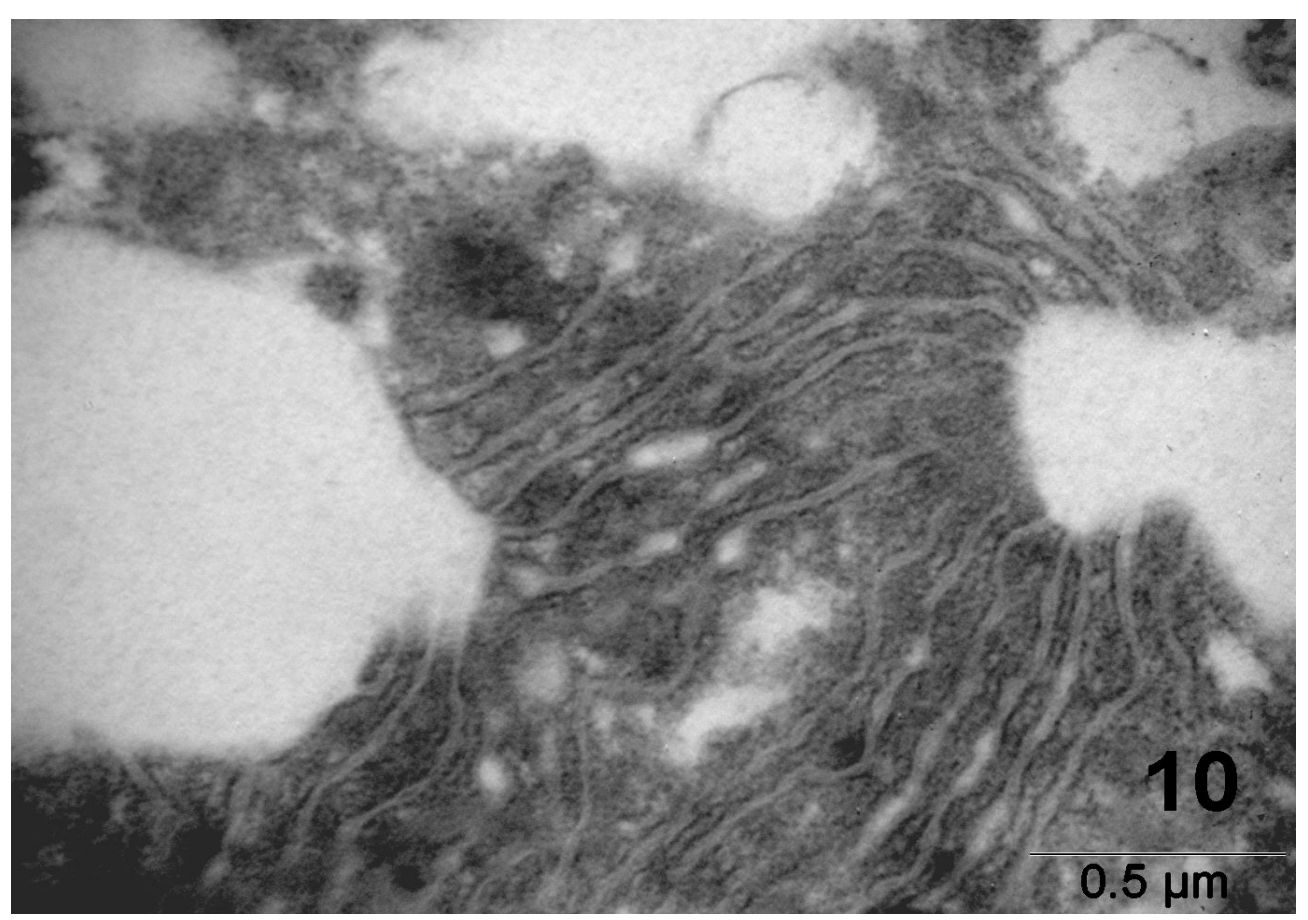

Fig. 10. Control immunoreaction to LOX (no particles) in the dilated RER of tapetum at vacuolated pollen stage. Bar: $0.5 \mu \mathrm{m}$

\section{Conclusions}

Overall the results reported in this paper demonstrate that LOX increase which took a role in the membrane degeneration, possibly induced the collapse of tonoplast, nuclear and plasma membrane and triggered PCD in the tapetal cells of $L$. undulatus as well as the other wall cells. The best of our knowledge is, this is the first report of localization of LOX during developmental PCD in anthers.

\section{Acknowledgements}

This work was supported by Research Foundation of Marmara University (BAPKO no: FEN-DKR 1511050227).

\section{References}

Axerold B, Chesbrough TM, Laakso S (1981). Lipoxygenase from soybean. Methods enzymology. Academic press, New York, 441-451.

Bowsher CG, Ferrie BJM, Ghosh S, Todd J, Thompson JE, Rothstein SJ (1992). Purification and partial characterization of a membrane-associated lipoxygenase in tomato fruit. Plant Physiol 100:1802-1807.

Bunaurio R, Servili M (1999). Involvement of lipoxygenase, lipoxygenase pathway volatiles, and lipid peroxidation during the hypersensitive reaction of pepper leaves to Xanthomonas campestris pv. vesicatoria. Physiol Mol Plant Pathol 54:155169.

Buranasompob A, Tang J, Powers JR, Reyes J, Clark S, Swanson
BG (2007). Lipoxygenase activity in walnuts and almonds. Lwt-Food Sci Technol 40:893-899.

Conconi A, Smerdon MJ, Howe GA, Ryan CA (1996). The octadecanoid signalling pathway in plants mediates a response to ultraviolet radiation. Nature 383:826-829.

Croft KPC, Voisey CR, Slusarenko AJ (1990). Mechanism of hypersensitive cell collapse: correlation of increased lipoxygenase with membrane damage in leaves of Phaseolus vulgaris (L.) cv. RedMexican inoculated with avirulent race 1 of Pseudomonas syringae pv. phaseolicola. Physiol Mol Plant Pathol 36:49-62.

Fadok VA, Bratton DL, Frasch SC, Warner ML, Henson PM (1998). The role of phosphatidylserine in recognition of apoptotic cells by phagocytes. Cell Death Differ 5:551-562.

Feussner I, Balkenhohl TJ, Porzel A, Kühn H, Wasternack C (1997). Structural elucidation of oxygenated storage lipids in cucumber cotyledons. J Biol Chem 272:21635-21641.

Galliard T, Chan HWS (1980). Lipoxygenases, vol. 4, p. 131161. In: Stumpf PK, Conn EE (Eds.). The biochemistry of plant. Academic Press Inc, New York, USA.

Gigot C, Ongena M, Fauconnier, ML, Wathelet JP, Jardin PD, Thonart P (2010). The lipoxygenase metabolic pathway in plants: potential for industrial production of natural green leaf volatiles. Biotechnol Agron Soc Environ 14:451-460.

Hale AJ, Smith CA, Sutherland LC, Stoneman VEA, Longthorne VL, Culhane AC and Williams GT (1996). Apoptosis: molecular regulation of cell death. Eur J Biochem 236:1-26.

Hockenbery DM, OltvaiZN, Yin XM, Milliman CL, Korsmeyer 
78

SJ (1993). Bcl-2 functions in an antioxidant pathway to prevent apoptosis. Cell 75:241-251.

Kato T, Ohta H, Tanaka K, Shibata D (1992). Appearance of new lipoxygenases in soybean cotyledons after germination and evidence for expression of a major new lipoxygenase gene. Plant PhysioL 98:324-330.

Lorenzi V, Maury J, Casanova J, Berti L (2006). Purification, product characterization and kinetic properties of lipoxygenase from olive fruit (Olea europaea L). Plant Physiol Biochem 44:450-454.

Lynch DV, Thompson JE (1984). Lipoxygenase-mediated production of superoxide anion in senescing plant tissue. FEBS Lett 173:251-254.

Maccarrone M, Bellincampi L, Melino G, Finazzi-Agrò A (1998). Cholesterol, but not its esters, triggers programmed cell death in human erythroleukemia K562 cells. Eur J Biochem 253:107-113.

Maccarrone M, Lorenzon T, Guerrieri P, Finazzi-Agrò A (1999). Resveratrol prevents apoptosis in K562 cells by inhibiting lipoxygenase and cyclooxygenase activity. Eur J Biochem 265:27-34.

Maccarrone M, Van Zadelhoff G, Valdink GA, Vliegenthart JFG, Finazzi-Agrò A (2000). Early activation of lipoxygenase in lentil (Lens culinaris) root protoplasts by oxidative stress induces programmed cell death. Eur J Biochem 267:5078 5084.

Porta H, Rocha-Sosa M (2002). Plant lipoxygenases: Physiological and molecular features. Plant Physiol 130:1521.

Porta H, Rueda-Benitez P, Campos F, Colmenero-Flores JM, Colorado JM, Carmona MJ, Covarrubias AA, Rocha-Sosa M (1999). Analysis of lopoxygenase mRNA accumulation in the common bean (Phaseolus vulgaris L.) during development and under stress conditions. Plant Cell Physiol 40:850-858.

Rusterucci C, Montillet JL, Angel JP, Battesti C, Alonso B, Knoll A, Bessoule J, Etienne P, Suty L, Blein JP, Triantaphylides C (1999). Involvement of lipoxygenase-dependent production of fatty acid hydroperoxides in the development of the hypersensitive cell death induced by cryptogein on tobacco leaves. J Biol Chem 274:36446-36455.
Schmitt NF, Van Mechelen JR (1997). Expression of lipoxygenase isoenzymes in developing barley grains. Plant Sci 128:141-150.

Siedow J (1991). Plant lipoxygenase structure and function. Annu Rev Plant Physiol Plant Mol Biol 42:145-188.

SzczukaE, Skórzyńska-PolitE, Pawlikowska-Pawlęga B, Sobieska J, Gawron A (2006). Immunolocalization of lipoxygenase in the anther of Gagea lutea (L.) Ker-Gaw. Acta Bot Cracov 48:19-26.

Todd JF, Paliyath G, Thompson JE (1990). Characteristic of a membrane-associated lipoxygenase in tomato fruit. Plant Physiol 94:1225-1232.

Torres-Roca JF, Lecoeur H, Amatore C, Gougeon ML (1995). The early intracellular production of reactive oxygen intermediate mediates apoptosis in apoptosis in dexamethasone-treated thymocytes. Cell Death Differ 2:309-319.

Vardar F (2008). Development and programmed cell death in the anthers of Lathyrus undulatus Boiss. Marmara Uni., Meral Ünal, PhD Diss. Results 41-134.

Vardar F, Ünal M (2011). Cytochemical and ultrastructural observations of anthers and pollen grains in Lathyrus undulatus Boiss. Acta Bot Croat 70:53-64.

Vianello A, Braidot E, Bassi G, Macri F (1995). Lipoxygenase activity on the plasmalemma of sunflower protoplasts and its modulation. Biochim et Biophy Acta 1255:57-62.

Wagenknecht B, Gulbins E, Lang F, Dichgans J, Weller M (1997). Lipoxygenase inhibitors block CD95 ligandmediated apoptosis of human malignant glioma cells. FEBS Lett 409:17-23.

Wang C, Jarlfors U, Hildebrand D (1999). Regulation and subcellular localization of auxin-induced lipoxygenases. Plant Sci 148:147-153. 